\title{
ANALISIS KEUNTUNGAN PEDAGANG PENGECER DAGING SAPI DI PASAR TRADISIONAL KOTA MANADO
}

\author{
Nicolas Butarbutar*, B. Rorimpandey**, R.A.J. Legrans ** \\ I.D.R. Lumenta**
}

Fakultas Peternakan, Universitas Sam Ratulangi Manado 95115

\begin{abstract}
ABSTRAK
Penelitian dilaksanakan di pasar tradisional Kota Manado, khususnya Pedagang Pengecer di pasar tradisional Bersehati dan pasar Pinasungkulan Ranotana. Masalah dalam penelitian ini adalah berapa besar biaya operasional yang dikorbankan pedagang pengecer dalam aktivitas pemasaran daging sapi serta apakah aktivitas pedagang pengecer daging sapi memberikan keuntungan jika dibandingkan dengan tingkat suku bunga bank. Tujuan penelitian adalah untuk mengetahui berapa besar penggunaan biaya operasional pedagang pengecer dan berapa besar keuntungan yang diterima pedagang pengecer di pasar tradisional Kota Manado. Sumber data dalam penelitian ini yakni data primer dan data sekunder. Penentuan sampel dilakukan secara purposive sampling. Model analisis data dalam penelitian ini menggunakan pendekatan analisis deskriptif dan analisis matematika serta konsep rentabilitas. Hasil penelitian menunjukkan bahwa rata-rata biaya operasional yang digunakan pedagang pengecer dalam pemasaran daging sapi sebesar Rp.60.000.258 perminggu atau sebesar Rp.239.990.725 perbulan. Besarnya keuntungan yang diterima pedagang pengecer daging sapi yaitu rata-rata Rp.3.703.093 perminggu atau sebesar Rp.14.822.681 perbulan. Usaha pedagang pengecer daging sapi di pasar tradisional Kota Manado mampu memberikan keuntungan. Usaha ini
\end{abstract}

*Alumni Fakultas Peternakan Unsrat **Jurusan Sosial Ekonomi Peternakan secara keseluruhan mampu mencapai nilai rentabilitas yang lebih baik dibandingkan dengan tingkat suku bunga Bank Indonesia yang berlaku. Rata-rata nilai rentabilitas pedagang pengecer daging sapi sebesar 7,01\% per bulan $(84,16 \%$ per tahun) sementara suku bunga Bank Indonesia (SBBI) yang berlaku sebesar 7,5\%.

Kata Kunci: Keuntungan, Pengecer, Daging sapi, Pasar Tradisional, Manado.

\section{ABSTRACT}

$\begin{array}{llr}\text { BENEFIT ANALYSIS OF RETAIL } \\ \text { TRADERS } & \text { AT } & \text { BEEF } \\ \text { TRADITIONAL } & \text { MARKET } & \text { IN } \\ \text { MANADO. The } & \text { experiment } & \text { was }\end{array}$
conducted at beef traditional market in Manado, particularly at "Bersehati Jengki market region" and "Pinasungkulan Ranotana market region". The problem in this study is how much the operating costs retailers spent in beef marketing activity and how much the benefit of beef marketing activity received by retailers when compared with the bank interest rate level. The purpose of the study was to find out the operating cost spent by retailers compared with the benefit in beef marketing activity in Manado traditional markets. Sources of data in this study were found from the primary and secondary data. The samples were taken using purposive sampling method. Data analysis model in this study were conducting by descriptive analysis approach and mathematical analysis as 
well as the concept of profitability. The results of the study showed that the average operating costs used by retailers in beef marketing were $\mathrm{Rp} 60,000,258$ per week or Rp 239,990,725 per month. The average amount of the benefits received by retailers in beef marketing were $\mathrm{Rp} 14,822,681$ per week or $\mathrm{Rp}$ 3,703,093 per month. Enterprises of beef retailers in Manado traditional markets were able to gain the benefit. This business is also able to achieve the better overall profitability value compared with the bank rate prevailing in Indonesia. The average value of profitability of beef retailers was $7.01 \%$ per month $(84.16 \%$ per year) while the bank rate of Indonesia (SBBI) was $7.5 \%$.

Keywords: Profit, Retailers, Beef, Traditional Market, Manado

\section{PENDAHULUAN}

Sub sektor peternakan sebagai salah satu bagian dari sektor pertanian, mempunyai peranan penting untuk menunjang kebutuhan masyarakat dalam penyediaan bahan makanan berupa protein asal ternak. Salah satu usaha peternakan yang dapat menunjang kebutuhan masyarakat akan protein hewani asal ternak ialah produk daging sapi. Produk daging sapi tersebut memiliki sumber protein yang kaya akan asam amino essensial. Daging sapi berperan penting dalam perkembangan kecerdasan sumber daya manusia. Produk daging sapi berperan juga dalam memberikan kontribusi terhadap aspek sosial maupun aspek ekonomi.

Usaha peternakan memiliki tujuan antara lain untuk memenuhi kebutuhan masyarakat akan protein hewani asal ternak yang bermutu baik. Tujuan lain usaha peternakan sebagai salah satu bahan baku dalam mengembangkan industri peternakan dan perdagangan bahan-bahan asal ternak.

$\begin{array}{lccr} & \text { Pemasaran } & \text { memiliki } & \text { fungsi } \\ \text { yang sangat } & \text { penting } & \text { dalam } \\ \text { menghubungkan } & \text { produsen } & \text { dengan } \\ \text { konsumen dan } & \text { memberikan nilai } \\ \text { tambah yang } & \text { besar dalam }\end{array}$
perekonomian. Sistem distribusi produk dari produsen ke konsumen dapat terdiri dari beberapa rantai tataniaga (marketing channels). Pelaku pasar tersebut masing-masing memberikan jasa yang berbeda.

Pedagang pengecer di pasar tradisional Kota Manado merupakan bagian dari jasa perdagangan yang mempunyai peranan penting terhadap aktivitas pemasaran. Peranan pedagang pengecer di Kota Manado khususnya pada aktivitas pemasaran daging sapi sudah berlangsung cukup lama dan mampu 
memenuhi permintaan daging sapi baik dalam jumlah, bentuk maupun waktu yang diinginkan oleh pihak konsumen. Aktivitas pemasaran daging sapi yang dilaksanakan oleh pedagang pengecer di pasar tradisional Kota Manado didukung oleh adanya kelancaran dalam pemasaran daging sapi melalui rumah potong hewan maupun yang langsung dari peternak sapi.

Ketidakmampuan daya beli masyarakat terhadap produk daging sapi diduga karena daging sapi relatif mahal. Akhir-akhir ini daging sapi telah mengalami peningkatan harga sehingga sulit di jangkau masyarakat yang berpenghasilan menengah ke bawah.

$$
\begin{aligned}
& \text { Pasar tradisional di Kota } \\
& \text { Manado terdapat dua pasar yang } \\
& \text { menjual daging sapi yaitu, Pasar } \\
& \text { Pinasungkulan Ranotana dan Pasar } \\
& \text { Bersehati Calaca. Beberapa } \\
& \text { pedagang pengecer daging sapi yang } \\
& \text { berjualan di pasar-pasar tersebut } \\
& \text { berasal dari luar Kota Manado yakni } \\
& \text { berasal dari Minahasa, Tomohon } \\
& \text { bahkan dari Gorontalo. Pedagang } \\
& \text { pengecer yang melaksanakan } \\
& \text { aktivitas pemasaran daging sapi di } \\
& \text { pasar tradisional Kota Manado sudah }
\end{aligned}
$$

berlangsung cukup lama berkisar antara 10 sampai 20 tahun dan sudah menjadi mata pencaharian dalam memenuhi kebutuhan rumah tangga.

$$
\text { Harga pembelian dan }
$$
penjualan daging sapi bervariasi tergantung pada hari-hari raya keagamaan. Pedagang pengecer akan menaikan harga daging sapi pada saat ada hari raya keagamaan, dengan demikian dapat dikatakan bahwa pedagang pengecer sangat berperan dalam menentukan harga jual. Kenyataan ini, tentunya akan mendorong masyarakat peternak bahkan pedagang dalam melaksanakan aktivitas pemeliharaan serta aktivitas pemasaran daging sapi untuk memperoleh keuntungan sebagai nilai tambah dalam keluarga. Penelitian ini akan mengkaji berapa besar keuntungan yang diperoleh pedagang pengecer daging sapi di pasar tradisional Kota Manado akibat korbanan modal dalam aktivitas jual beli daging sapi dengan membandingkan tingkat suku bunga bank yang berlaku.

\section{MATERI DAN METODE PENELITIAN}


Penelitian ini dilaksanakan di pasar tradisional Kota Manado, khususnya pedagang pengecer di pasar tradisional Bersehati Calaca dan pasar Pinasungkulan Ranotana. Waktu penelitian yaitu mulai bulan Mei sampai Juni 2013.

Pengumpulan data dilakukan melalui metode survey (Cochran, 1991, Singarimbun dan Effendi, 1999). Sumber data dalam penelitian ini yakni data primer dan data sekunder. Data primer diperoleh dari pengamatan secara langsung terhadap pedagang pengecer yang melakukan aktivitas jual beli daging sapi. Data sekunder diperoleh dari instansi terkait dengan penelitian ini yaitu Perusahaan Daerah (PD) Pasar Kota Manado dan BPS SULUT.

Penentuan sampel dilakukan secara Purposive Sampling, atas dasar pertimbangan bahwa pedagang pengecer yang dijadikan sampel ialah pedagang pengecer tetap yakni sudah beraktivitas selama 10 tahun berturut-turut. Berdasarkan hasil pra survey pedagang pengecer yang beraktivitas di pasar tradisional kota Manado sebanyak 38 orang, terdiri dari pedagang pengecer tetap dan pedagang pengecer tidak tetap. Pedagang pengecer tidak tetap adalah pedagang musiman beraktivitas pada hari-hari tertentu, misalnya hari raya keagamaan. Berdasarkan pertimbangan tersebut, maka jumlah sampel yang dijadikan responden dalam penelitian ini sebanyak 26 orang pedagang pengecer daging sapi di pasar tradisional Kota Manado. Jumlah sampel pedagang pengecer daging sapi di pasar tradisional Kota Manado dapat dilihat pada Tabel 1.

Tabel 1. Jumlah Sampel Pedagang Pengecer Daging Sapi di Pasar Tradisional Kota Manado

\begin{tabular}{cccc}
\hline \multicolumn{1}{c}{ Nama Pasar } & \multicolumn{2}{c}{$\begin{array}{c}\text { Pedagang Pengecer } \\
(\text { Org })\end{array}$} & Jumlah Responden (Org) \\
\hline & Tetap & Musiman & \\
\hline Pasar Pinasungkulan Ranotana & 6 & 3 & 6 \\
Pasar Bersehati Calaca & 20 & 4 & - \\
Pasar Orde Baru Paal 2 & - & 2 & - \\
Pasar 66 Bahu & - & 1 & - \\
Pasar Tuminting & - & 2 & 26 \\
\hline Total & 26 & 12 & \\
\hline
\end{tabular}


Konsep, definisi variabel dan pengukurannya dalam penelitian ini adalah sebagai berikut :

1. Pasar tradisional ialah tempat terjadinya transaksi antara penjual dan pembeli daging sapi yang berlokasi di Kota Manado.

2. Pedagang pengecer ialah seseorang yang melaksanakan pemasaran secara tetap terhadap produk peternakan yakni daging sapi di pasar tradisional Kota Manado.

3. Daging sapi ialah produk peternakan sapi yang dipasarkan dan dibeli oleh konsumen $(\mathrm{Kg})$.

4. Harga ialah harga daging sapi yang berlaku pada saat penelitian, baik harga beli oleh pedagang pengecer maupun harga beli oleh konsumen akhir di pasar tradisonal Kota Manado ( $\mathrm{Rp} / \mathrm{Kg})$.

5. Volume penjualan ialah jumlah daging sapi yang terjual dalam sehari (Kg/hari).

6. Biaya pemasaran ialah seluruh biaya yang dikeluarkan oleh pedagang pengecer dalam aktivitas pemasaran daging sapi dalam sehari (berupa biaya transport, biaya tenaga kerja, biaya retribusi pasar, biaya pengemasan) (Rp/hari).

7. Penerimaan ialah jumlah penjualan daging sapi dikalikan harga jual (Rp/hari).

8. Keuntungan ialah uang yang diperoleh dari selisih jumlah yang diterima dari penjualan daging sapi dengan jumlah biaya yang dikeluarkan dalam aktivitas pemasaran daging sapi (Rp/hari).

9. Produktivitas laba ialah rasio antara laba dengan modal dala proses produksi selama periode tertentu, diukur dalam satuan persentase.

Model analisis data dalam penelitian ini menggunakan pendekatan analisis deskriptif dan analisis matematika. Pendekatan analisis deskriptif dimaksudkan untuk menguraikan secara kualitatif keadaan riil mata rantai pemasaran daging sapi yang berlaku di pasar tradisonal Kota Manado dan menguraikan aktivitas pedagang pengecer daging sapi yang diuraikan dalam bentuk bagan, tabelaris ataupun prosentase. Sedangkan pendekatan analisis matematik dimaksudkan untuk menganalisis : 
1) Alokasi penggunaan biaya operasional pemasaran daging sapi.

2) Besarnya keuntungan digunakan analisis matematik: $\pi=\mathrm{TR}-\mathrm{TC}$

Keterangan :

$\pi=$ Keuntungan

$\mathrm{TR}=$ Total Revenue $($ Total Pnerimaan)

$\mathrm{TC}=$ Total Cost $($ Total Biaya $)$

3) Besarnya tingkat rentabilitas laba dari aktivitas pemasaran daging sapi dilakukan dengan menggunakan pendekatan konsep rentabilitas. Rentabilitas ialah perbandingan antara laba dengan biaya operasional yang digunakan untuk menghasilkan laba yang dinyatakan dalam persen (Nitisemito, 1984 dan Sinungan, 1997). Model analisisnya sebagai berikut :

$$
\mathrm{R}=\frac{\mathrm{L}}{\mathrm{C}}
$$

Keterangan : $\mathrm{R}=$ Rentabilitas

$\mathrm{L}=$ Laba

$\mathrm{C}=$ Biaya operasional
Aktivitas Pedagang Pengecer Dalam Jual-Beli Daging Sapi di Pasar Tradisional Kota Manado Hasil penelitian menunjukkan bahwa, tidak semua pedagang pengecer mendapatkan daging sapi dari pedagang pengumpul. Aktivitas pemasaran sebagiannya dilakukan dengan membeli langsung dari peternak sapi yang kemudian disembelih sendiri selanjutnya dijual ke konsumen. Rata-rata pedagang pengumpul biasanya mendapatkan ternak sapi dari luar wilayah Manado, seperti wilayah Kotamobagu, Bolaang Mongondow bahkan ada juga yang dari Gorontalo. Hal ini yang menyebabkan waktu dan tenaga kerja yang dibutuhkan dalam pengadaan ternak sapi untuk disembelih lebih besar. Saluran pemasaran daging sapi yang berlaku di pasar Bersehati dan Pinasungkulan Manado berlaku dua jenis saluran yaitu, (1) dari kepada pedagang pengumpul/RPH kepada pedagang pengecer dan dari pedagang pengecer kepada konsumen, (2) peternak kepada pedagang pengecer dan dari pedagang pengecer langsung ke konsumen

\section{HASIL DAN PEMBAHASAN}


1.

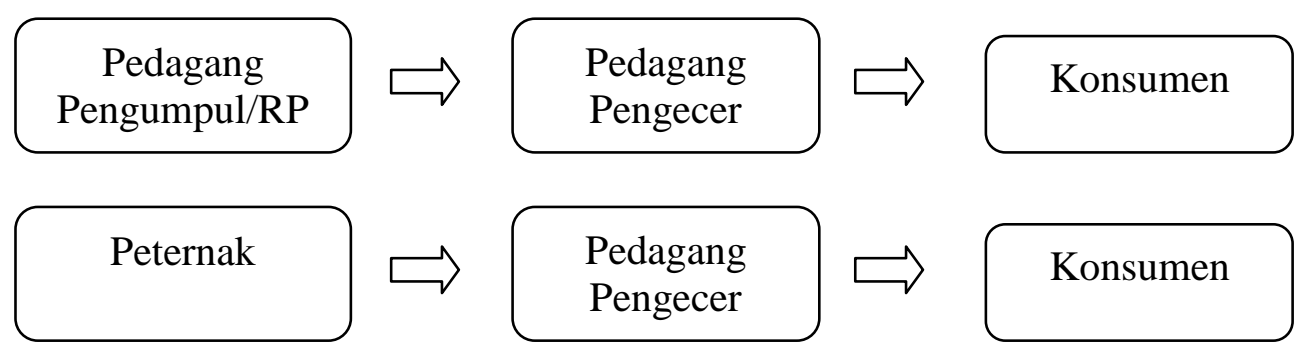

Gambar 1. Pemasaran Daging Sapi di Pasar Tradisional Kota Manado

Saluran pemasaran diatas menggambarkan situasi jaringan pemasaran yang berbeda-beda. Hasil penelitian menunjukkan bahwa, pedagang pengecer yang membeli daging sapi dari pedagang pengumpul (berfungsi sebagai peternak) untuk dijual kepada konsumen terdapat 22 (dua puluh dua) orang. Harga beli per kilogram daging sapi bervariasi antara Rp.70.000 sampai Rp.75.000 per kilogram serta harga jualnya Rp.80.000 per kilogram. Sedangkan empat orang pedagang pengecer yang menjual daging sapi bersumber dari hasil pembelian pada peternak lain dan kemudian disembelih sendiri. Daging sapi yang dijual pedagang pengecer terdapat perbedaan baik dalam bentuk, volume pembelian dan penjualan maupun harga beli dan harga jual.
Hasil penelitian menunjukkan ternyata volume pembelian dan penjualan berkaitan erat dengan modal yang harus dikorbankan untuk mendapatkan daging sapi baik dari pedagang pengumpul maupun peternak. Perbedaan volume penjualan tersebut diakibatkan karena adanya perbedaan berat badan ternak sapi setelah isi perut dikeluarkan.

Harga beli ternak oleh pedagang daging sapi dari peternak banyak dipengaruhi oleh harga jual yang berlaku di pasar dan jumlah permintaan konsumen terhadap daging sapi. Menurut Oentoro (2010), mekanisme terbentuknya harga adalah proses yang berjalan atas dasar kekuatan tarik menarik antara konsumen dan produsen yang bertemu di pasar. Hal ini disebabkan karena harga suatu produk bergeser naik apabila permintaan terhadap 
suatu produk meningkat, sebaliknya suatu produk bergeser turun apabila permintaan suatu produk berkurang.

Berdasarkan hasil penelitian diperoleh bahwa, rata-rata harga jual yang berlaku selama satu minggu menurut bagian-bagiannya yaitu daging utuh Rp.74.792 per kilogram (24 responden), daging campur Rp.39.091 per kilogram (11 responden), tulang sapi Rp.29.845 per kilogram (23 responden), jeroan Rp.31.272 per kilogram (16 responden), tetelan Rp.43.730 per kilogram (9 responden). Harga jual produk ternak sapi di atas terbentuk akibat adanya transaksi jual-beli antara pedagang pengecer dengan konsumen di pasar. Fenomena ini menunjukkan berlakunya hukum permintaan dan penawaran terhadap suatu produk.

Indikator yang digunakan dalam menentukan rata-rata harga jual per kilogram adalah perbandingan antara besarnya penerimaan dalam rupiah yang diperoleh dengan jumlah volume jual dalam kilogram. Hal ini dilakukan karena adanya kesulitan untuk mendapatkan rata-rata harga jual per kilogram akibat para pedagang dalam menjual daging sapi banyak ditentukan oleh konsumen dalam membeli. Kondisi tersebut dilihat dari adanya konsumen yang hanya membeli daging utuh, ada pula yang membeli tulang saja atau daging campur saja. Hal inilah yang menyulitkan untuk mendapatkan berapa rata-rata harga jual per kilogram.

\section{Biaya Pemasaran dan Modal Pemasaran Daging Sapi}

Biaya pemasaran mencakup seluruh kegiatan dari perencanaan pemasaran sampai pada tangan konsumen akhir. Biaya pemasaran ialah semua pengeluaran yang harus dikeluarkan pedagang pengecer untuk memperoleh produk ternak sapi (daging, tulang, tetelan, jeroan dan daging campur). Besarnya modal dan biaya pemasaran sangat tergantung dari besarnya skala usaha yang diusahakan (Raysaf, 2000).

Modal dan biaya pemasaran daging sapi dalam penelitian ini ialah keseluruhan biaya yang dikeluarkan oleh pedagang pengecer daging sapi. Biaya-biaya tersebut seperti biaya pembelian daging, tulang, tetelan, jeroan dan daging campur, dan biaya transportasi, tenaga kerja, retribusi 
(kebersihan dan lokasi/tempat jual) dan pengepakan (kemasan) serta biaya di RPH .

Berdasarkan hasil penelitian diperoleh bahwa, rata-rata modal dan biaya pemasaran daging sapi per minggu oleh responden dapat dilihat pada Tabel 2. Berdasarkan Tabel 2, ternyata rata-rata biaya transportasi yang dikeluarkan oleh ke 26 pedagang pengecer sebesar Rp.224.423 per minggu. Hasil penelitian menunjukkan bahwa, terdapat variasi biaya transportasi dari setiap pedagang pengecer, antara Rp.70.000 sampai Rp.525.000 per minggu. Biaya transportasi yang besar disebabkan pengadaan ternak sapi bukan hanya berlokasi di sekitar wilayah Manado tetapi juga di luar wilayah Manado seperti wilayah Kotamobagu sampai Bolaang Mongondow Timur. Biaya ini termasuk biaya transportasi dari rumah ke pasar.

Tabel 2. Rata-rata Biaya beli dan Biaya Pemasaran Daging Sapi di Pasar Tradisional Kota Manado (Per minggu)

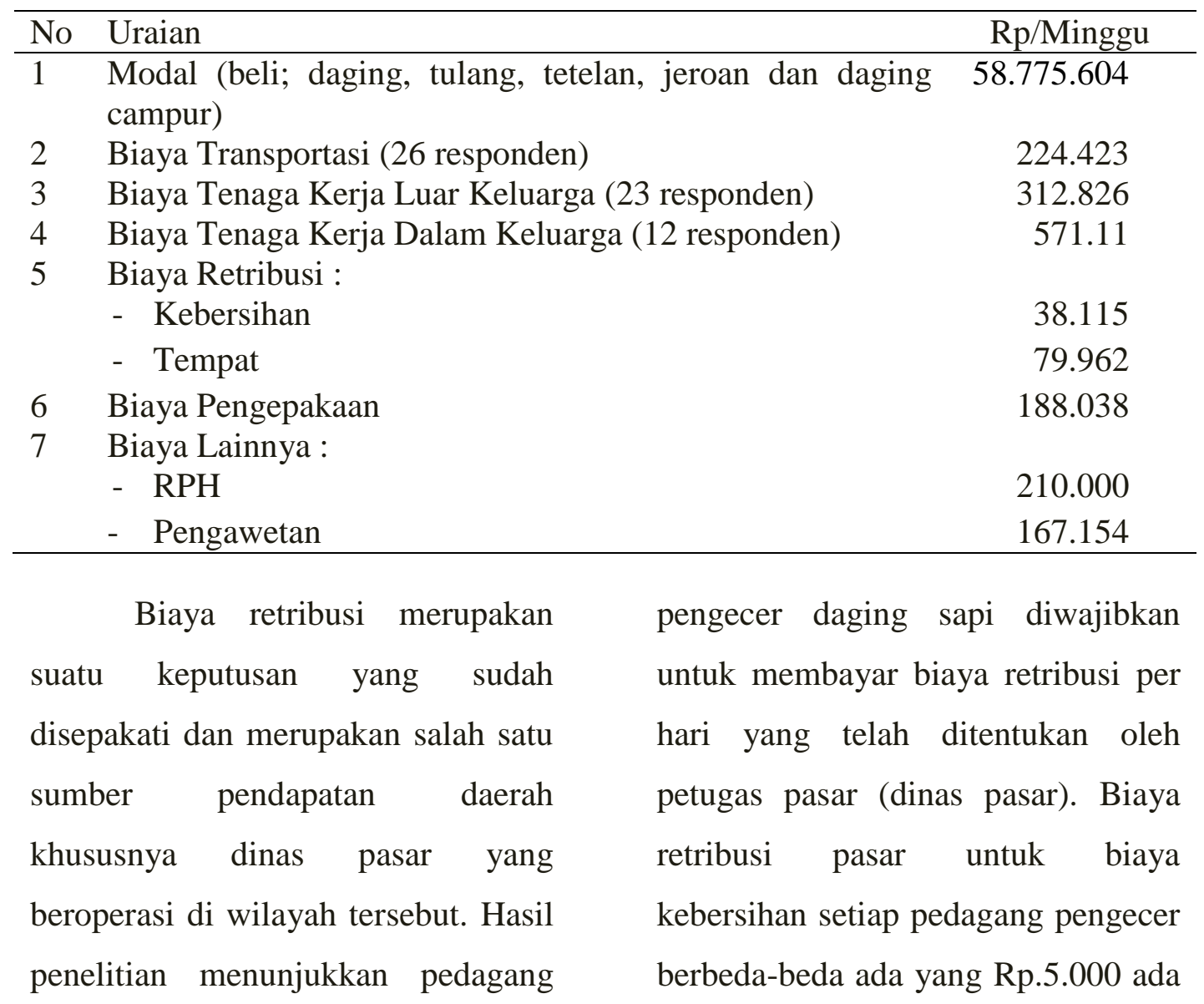


pula Rp.6.000 per hari. Biaya retribusi meja tempat mereka berjualan juga berbeda-beda mulai dari Rp.6000 sampai Rp.15.000 per hari. Besarnya biaya ini tergantung dari ukuran meja tempat berjualan karena semakin besar ukuran mejanya maka biaya retribusinya semakin besar.

Biaya tenaga kerja yang berlaku di pasar Bersehati dan pasar Pinasungkulan Ranotana adalah per hari. Pedagang pengecer memperhitungkan upah tenaga kerja baik dalam keluarga maupun luar keluarga. Upah tenaga kerja dalam keluarga rata-rata per minggu $\mathrm{Rp}$. 571.111 sedangkan tenaga kerja luar keluarga rata-rata per minggu Rp.312.826. Biaya tenaga kerja bervariasi dari Rp.50.000 sampai dengan Rp.100.000 per hari. Biasanya upah tersebut diberikan setelah mereka menyelesaikan pekerjaan atau setelah jam kerja habis.

\section{Biaya kemasan berupa} kantong plastik sebagai tempat daging sapi yang dibeli oleh pedagang pengecer daging sapi ratarata sebesar Rp.188.038 per minggu. Biaya lainnya disini berupa biaya pengawetan meliputi biaya air, biaya untuk es batu serta biaya RPH. Biaya pengawetan satu minggu sebesar Rp.167.154, sedangkan untuk tarif yang diberikan oleh RPH pada satu ekor ternak sapi untuk dibantai sebesar Rp. 30.000 sehingga untuk satu minggu rata-rata biaya RPH sebesar Rp. 210.000.

Biaya terbesar dalam pemasaran daging sapi ialah biaya pembelian daging sapi oleh pedagang pengecer kepada pedagang pengumpul, yakni rata-rata sebesar Rp.58.775.604 perminggu. Hal yang menarik dari setiap pedagang pengecer adalah mereka sudah memiliki atau mempunyai pelanggan tetap dalam memasarkan produk daging sapi tersebut. Pelanggan tetap mereka berupa rumah makan atau restourant, pedagang bakso, pedagang soto, serta masyarakat yang membeli daging sapi setiap hari. Rata-rata rumah makan atau restourant serta para pedagang bakso dan soto mereka membeli daging sapi dari pedagang pengecer sebanyak 50-75 kilogram perhari.

\section{Penerimaan, Keuntungan Pedagang Pengecer dan Rentabilitas}


Penerimaan ialah nilai rupiah yang diterima pedagang pengecer dari hasil penjualan daging sapi. Menurut Sakti (2007), penerimaan ialah nilai produk yang dihasilkan dari suatu usaha dikalikan dengan harga yang berlaku. Berdasarkan hasil penelitian diperoleh bahwa, rata-rata penerimaan daging, tulang, jeroan, tetelan serta daging campur di pasar tradisional Kota Manado dalam seminggu pedagang pengecer dapat dilihat pada Tabel 3.

Tabel 3. Rata-Rata Jumlah Penjualan, Harga Beli, Harga Jual, Penerimaan dan Pendapatan Dalam Seminggu

\begin{tabular}{lllllll}
\hline No & Uraian & $\begin{array}{l}\text { Jlh } \\
(\mathrm{kg})\end{array}$ & $\begin{array}{l}\text { Harga } \\
\text { Beli } \\
(\mathrm{Rp})\end{array}$ & $\begin{array}{l}\text { Harga } \\
\text { Jual } \\
(\mathrm{Rp})\end{array}$ & $\begin{array}{l}\text { Pendapatan } \\
(\mathrm{Rp})\end{array}$ & $\begin{array}{l}\text { Penerimaan } \\
(\mathrm{Rp})\end{array}$ \\
\hline 1 & Daging (24 resp.) & 715 & 74.792 & 80.000 & 3.654 .271 & 57.235 .000 \\
2 & Tulang (23 resp.) & 167 & 29.845 & 35.155 & 887.702 & 5.909 .876 \\
3 & Jeroan (16 Resp.) & 141 & 31.272 & 36.290 & 770.156 & 5.180 .848 \\
4 & Tetelan (9 resp.) & 63 & 43.730 & 48.651 & 313.175 & 2.977 .302 \\
5 & $\begin{array}{l}\text { Daging Campur } \\
\text { (11 resp) }\end{array}$ & 73 & 39.091 & 44.740 & 441.883 & 3.366 .429 \\
\hline
\end{tabular}

Tabel 3 di atas menunjukkan bahwa, rata-rata pendapatan masingmasing bagian diperoleh dari harga jual dikali dengan jumlah kilogram dikurangi dengan harga beli dikali jumlah kilogram. Sedangkan ratarata penerimaan masing-masing bagian diperoleh dari harga jual dikali dengan jumlah kilogram.
Berdasarkan hasil penelitian yang diperoleh, rata-rata besarnya keuntungan pedagang pengecer daging sapi di pasar Bersehati dan pasar Pinasungkulan yaitu Rp.3.703.093 per minggu atau ratarata per bulan sebesar Rp.14.822.681 (Tabel 4).

Tabel 4. Rata-Rata Keuntungan Pedagang Pengecer Daging Sapi

\begin{tabular}{llrr}
\hline No & Uraian & Rp/Minggu & \multicolumn{1}{c}{ Rp/Bulan } \\
\hline 1 & Penerimaan & 63.703 .352 & 254.813 .407 \\
2 & Biaya Operasional & 60.000 .258 & 239.990 .725 \\
3 & Keuntungan & 3.704 .093 & 14.822 .681 \\
\hline
\end{tabular}

Tabel 4 menunjukkan bahwa, adanya perbedaan besar keuntungan masing-masing pedagang pengecer daging sapi dikarenakan adanya perbedaan jumlah volume kilogram yang dipasarkan dan harga oleh 
masing-masing pedagang pengecer. Hal ini sejalan dengan pendapat Kottler (1998), bahwa besarnya keuntungan yang diperoleh dari hasil pemasaran suatu produk banyak faktor yang mempengaruhi antara lain harga, jumlah permintaan, transportasi dan sebagainya. Pendapat tersebut dipertegas oleh Rasyaf (2000) bahwa, perolehan keuntungan pemasaran dipengaruhi berbagai faktor antara lain, harga beli produk, harga jual dan volume penjualan serta jumlah permintaan konsumen. Menurut Mursid (1993), besarnya keuntungan yang diterima dalam aktivitas pemasaran suatu produk banyak dipengaruhi oleh harga produk dan jumlah permintaan konsumen, karena semakin banyak permintaan terhadap suatu produk, pihak pedagang akan termotivasi untuk berusaha menjual produk tersebut.

Hasil analisis rentabilitas masing-masing pedagang pengecer daging sapi disajikan pada Tabel 5 . Nilai rentabilitas yang dicapai masing-masing pedagang pengecer daging sapi di pasar Bersehati dan pasar Pinasungkulan Kota Manado lebih baik dari tingkat Suku Bunga Bank Indonesia (SBBI) yang berlaku yaitu Suku Bunga Bank Indonesia sebesar 7,5\% per tahun. Rata-rata tingkat rentabilitas yang ada pada pedagang pengecer daging sapi di pasar Bersehati dan pasar Pinasungkulan Kota Manado sebesar $7,01 \%$ per bulan. Tingkat rentabilitas $7,01 \%$ per bulan merupakan nilai yang dikategorikan baik, hal ini berarti setiap penggunaan biaya pemasaran daging sapi di pasar Bersehati dan pasar Pinasungkulan Kota Manado sebesar Rp.100 akan mampu menghasilkan laba sebesar Rp.7,01. Nilai ini bila dibandingkan dengan tingkat Suku Bunga Bank Indonesia (SBBI) sebesar 7,5\% per tahun berarti biaya pemasaran yang digunakan dalam aktivitas pemasaran daging sapi tersebut masih memberikan tingkat rentabilitas yang lebih baik karena bernilai 7,01\% per bulan. 
Tabel 5. Nilai Rentabilitas Masing-masing Pedagang Pengecer Daging Sapi di Pasar Tradisional Kota Manado (per bulan)

\begin{tabular}{lrrrr}
\hline No & $\begin{array}{l}\text { Penerimaan } \\
(\mathrm{Rp})\end{array}$ & $\begin{array}{l}\text { Biaya Pemasaran } \\
(\mathrm{Rp})\end{array}$ & $\begin{array}{l}\text { Keuntungan } \\
(\mathrm{Rp})\end{array}$ & $\begin{array}{l}\text { Rentabilitas } \\
(\%)\end{array}$ \\
\hline 1 & 96.800 .000 & 88.424 .000 & 8.376 .000 & 9,47 \\
2 & 259.280 .000 & 240.846 .000 & 18.434 .000 & 7,65 \\
3 & 367.640 .000 & 347.664 .000 & 19.976 .000 & 5,75 \\
4 & 298.080 .000 & 281.988 .000 & 16.092 .000 & 5,71 \\
5 & 377.600 .000 & 356.988 .000 & 20.612 .000 & 5,77 \\
6 & 409.300 .000 & 385.748 .000 & 23.552 .000 & 6,11 \\
7 & 140.520 .000 & 131.322 .000 & 9.198 .000 & 7,00 \\
8 & 476.340 .000 & 448.848 .000 & 27.492 .000 & 6,13 \\
9 & 137.240 .000 & 130.368 .000 & 6.872 .000 & 5,27 \\
10 & 226.000 .000 & 214.432 .000 & 11.568 .000 & 5,39 \\
11 & 420.900 .000 & 397.956 .571 & 22.943 .429 & 5,77 \\
12 & 103.240 .000 & 96.748 .000 & 6.492 .000 & 6,71 \\
13 & 204.060 .000 & 189.340 .000 & 14.720 .000 & 7,77 \\
14 & 392.000 .000 & 375.080 .000 & 16.920 .000 & 4,51 \\
15 & 140.700 .000 & 132.988 .000 & 7.712 .000 & 5,80 \\
16 & 118.400 .000 & 107.120 .000 & 11.280 .000 & 10,53 \\
17 & 594.960 .000 & 563.768 .000 & 31.192 .000 & 5,53 \\
18 & 466.000 .000 & 439.380 .000 & 26.620 .000 & 6,06 \\
19 & 577.100 .000 & 549.288 .000 & 27.812 .000 & 5,06 \\
20 & 63.600 .000 & 56.300 .000 & 7.300 .000 & 12,97 \\
21 & 127.040 .000 & 116.265 .714 & 10.774 .286 & 9,27 \\
22 & 113.600 .000 & 106.388 .000 & 7.212 .000 & 6,78 \\
23 & 61.800 .000 & 54.552 .000 & 7.248 .000 & 13,29 \\
24 & 199.700 .000 & 189.440 .000 & 10.260 .000 & 5,42 \\
25 & 149.900 .000 & 141.992 .000 & 7.908 .000 & 5,57 \\
26 & 103.348 .571 & 96.524 .571 & 6.824 .000 & 7,07 \\
\hline Jumlah & 6.625 .148 .571 & 6.239 .758 .857 & 385.389 .714 & 182 \\
Rataan & 254.813 .407 & 239.990 .725 & 14.822 .681 & 7,01 \\
\hline & & & & \\
\hline
\end{tabular}

\section{KESIMPULAN}

Berdasarkan hasil penelitian dapat disimpulkan bahwa biaya pemasaran yang digunakan oleh pedagang pengecer dalam pemasaran daging sapi di pasar Tradisional Kota manado rata-rata sebesar
Rp.60.000.258 per minggu atau sebesar Rp.239.990.725 per bulan. Biaya pemasaran terdiri dari biaya pembelian daging, tulang, tetelan, jeroan dan daging campur daging sapi dan biaya transportasi, biaya retribusi pasar, biaya tenaga kerja, 
biaya pengepakan serta biaya lainnya (pengawetan dan administrasi RPH).

Besarnya keuntungan yang diterima pedagang pengecer daging sapi di pasar Tradisional Kota Manado yaitu rata-rata Rp.3.703.093 per minggu atau sebesar Rp.14.822.681 per bulan. Usaha pedagang pengecer daging sapi di pasar tradisional Kota Manado mampu memberikan keuntungan. Usaha pedagang pengecer daging sapi di pasar tradisional Kota Manado secara keseluruhan mampu mencapai rentabilitas yang lebih baik dibandingkan dengan tingkat suku bunga bank Indonesia yang berlaku yaitu rata-rata nilai rentabilitas dari pedagang pengecer daging sapi sebesar $7,01 \%$ per bulan $(84,16 \%$ per tahun) sementara Suku Bunga Bank Indonesia (SBBI) yang berlaku sebesar 7,5\% per tahun.

\section{DAFTAR PUSTAKA}

Cochran, W. G. 1991. Teknik Penarikan Sampel. Cetakan Pertama. Edisi Ketiga. Universitas Indonesia. Press. Jakarta
Kartasapoetra. 1994. Manajemen Pertanian. Bina Aksara. Jakarta

Kottler. 1998. Manajemen Pemasaran. Bumi Aksara. Jakarta.

Mursid, M. 1993. Manajemen Pemasaran. Bumi Aksara. Jakarta.

Nitisemito, A.S. 1984. Pembelanjaan Perusahaan (Revisi). Ghalia, Jakarta - Indonesia

Oentoro, D. 2010. Manajemen Pemasaran Moderen. Laksbang PRESSindo, Yogyakarta.

Rasyaf, M. 2000. Memasarkan Hasil Peternakan. Swadaya. Jakarta.

Sinungan , M. 1997. Produktivitas, Apa dan Bagaimana. Peberbit Bumi Aksara. Jakarta.

Singarimbun, M dan Effendi Sofian. 1999. Metode Penelitian Survey. LP3ES, Lembaga Penelitian, Pendidikan dan Penerangan Ekonomi dan Sosial. Jakarta 